\title{
The Effect of R\&D and the Control-Ownership Wedge on Firm Value: Evidence from Korean Chaebol Firms
}

\author{
Minjung Kang ${ }^{1}$, Sangil Kim ${ }^{2, *}$ and Moon-Kyung Cho ${ }^{3}$ (I) \\ 1 Department of Tax \& Accounting, Incheon National University, 119 Academy-ro, Yeonsu-gu, \\ Incheon City 406-772, Korea; mjkang@inu.ac.kr \\ 2 Department of Business Administration, Ajou University, 206 Worldcup-ro, Yeongtong-gu, \\ Suwon City 16499, Korea \\ 3 Division of International Banking \& Finance Studies, Texas A\&M International University, \\ 5201 University Boulevard, Laredo, TX 78041, USA; moonkyung.cho@tamiu.edu \\ * Correspondence: sikim@ajou.ac.kr; Tel.: +82-31-219-3633; Fax: +82-31-219-0440
}

Received: 9 April 2019; Accepted: 22 May 2019; Published: 26 May 2019

\begin{abstract}
Cases have been reported in which research and development (R\&D) investment, the core activity for a firm's sustainable growth, deteriorate rather than increase firm value. This study illuminates the cause of such cases in terms of the control-ownership wedge. How expensed and capitalized R\&D affect firm value are examined separately for cases in which the wedge is high and low. In an analysis of Korean chaebol firms, when the wedge is high, significant negative relationships appear between expensed $R \& D$ and firm value, while no significant relationship appears between capitalized R\&D and firm value. When the wedge is low, expensed $R \& D$ does not show any significant relationship with firm value, while capitalized $R \& D$ shows significant positive relationships with firm value. This confirms, first, that in cases of high wedge, suboptimal R\&D decisions are made, in which the manager can discretionally determine investment targets or projects. Second, this indicates that even in cases of low wedge, the positive relationship between R\&D and firm value does not appear in expensed R\&D. This study suggests that investors and regulatory authorities should pay close attention to the initial stage of $R \& D$ in firms with high control-ownership wedges for sustainable economic growth.
\end{abstract}

Keywords: research and development investments; expensed research and development; capitalized research and development; control-ownership wedge; firm value

\section{Introduction}

Research and Development (R\&D) investments, the core activity for a firm's sustainable growth and competitive advantage, occasionally deteriorate firm value. This study illuminates the cause of such cases from the perspective of corporate governance. We investigate how the degree of divergence between voting rights and cash flow rights, known as the control-ownership wedge (henceforth "wedge"), impacts the relation between R\&D decisions and firm value. Furthermore, R\&D is classified as either expensed or capitalized to analyze how each stage of R\&D affects firm value when the wedge is high or low.

R\&D activities are the source of innovation and sustainable growth as firms maintain consistent profitability. Innovative activities that firms pursue are the core sources of future technologies, products, and services, which guarantee sustainable growth and create competitive advantages [1,2]. Therefore, good R\&D decision-making is key for firms in order to maintain and develop innovation capabilities. For example, firms are able to make epoch-making products or services based on creative knowledge production from $R \& D$ activities [3,4]. Numerous empirical studies have examined the effects of $R \& D$ 
on firm value [5-7]. For example, Callen and Morel [8] and Han and Manry [9] report that R\&D positively affects firm value. However, not all studies consistently reported positive results in the relation between R\&D and firm value.

This study delves into one cause of suboptimal R\&D decisions by focusing on the impact of the wedge in the relationship between R\&D and firm value. It is known that the corporate governance structures of Korean firms enable controlling shareholders who have a small number of shares to exercise substantive influence over affiliates belonging to large Korean business groups through the pyramidal governance structure and circular shareholdings with subsidiaries and affiliates $[10,11]$. Controlling shareholders govern the entire business group with a small number of shares, bringing about a disparity between cash flow rights (the controlling shareholders' actual ownership rights) and control rights (the share of controlling shareholders include their indirect control rights obtained via circular shareholdings of subsidiaries), and causing an agency problem between controlling shareholders and minority shareholders [12].

Previous studies consistently report that the agency problem of the wedge reduces firm value [12-15]. Recently, many studies have investigated how controlling shareholders reduce firm value by focusing on the channel of encroaching profits (e.g., [11,16,17]). Related studies suggest that investment behavior in the presence of a high wedge reduces firm value [18-22]. When the wedge is high, controlling shareholders have greater incentives to use firms' resources for perquisite consumption, empire building, and excessive compensation, rather than firm value maximization [18]. Controlling shareholders are known to make suboptimal investment decisions. This is because there is an imbalance between the risk resulting from their decision and the private benefits vested in them. Controlling shareholders enjoy the firms' entire profits through private consumption, but the costs borne by private consumption are limited to the small number of shares owned by them.

This study extends prior work by examining the effects of different stages of R\&D (expensed and capitalized) on firm value when the wedge is either high or low. Expensed R\&D refers to investments in unforeseeable targets or projects with low economic feasibility. Since investment expenditure items are not fixed and investment accounts are not determined, controlling shareholders may easily employ expensed R\&D to pursue private benefits (e.g., perquisite consumption, excessive compensation, or non-arm's length transactions). On the other hand, managers are less likely to exercise discretion over capitalized R\&D investment decisions because the target is clearly defined and the product is at the stage immediately before commercialization. Therefore, although R\&D is known to improve firm value as a whole, when the wedge is high, expensed $R \& D$ is expected to reduce firm value and capitalized R\&D is not.

Meanwhile, we expect that both expensed and capitalized R\&D will positively affect firm value in environments in which controlling shareholders have fewer incentives or opportunities to pursue private benefits when the wedge is low, based on a number of previous studies [5-7,23-26]. However, expensed R\&D may not show relationships with firm value as it is the initial stage of investment when economic feasibility is uncertain.

The samples in this study are firms listed on the Korea Stock Exchange (KSE) and the Korea Securities Dealers Automated Quotation (KOSDAQ) that have been designated as belonging to large Korean business groups (chaebols, hereafter) by the Korea Fair Trade Commission (KFTC) from 2001 to 2015. The KFTC classifies multiple firms into business groups when at least $30 \%$ of the issued stocks of each firm is owned by the largest shareholder, affiliated parties, or the largest shareholder who has an influence over the management of the firms. These firms are classified as large business groups when their asset size exceeds five trillion Korean won in the previous year. As of 2015, Samsung, Hyundai Motor Company, SK, LG, Lotte, and POSCO are classified as large business groups.

Among chaebols, unlisted firms and financial firms without necessary financial data have been excluded from the samples, resulting in a total of 1,342 samples. Korean chaebols are a suitable sample for this investigation for the following reasons. First, our investigation shows the results of R\&D in different stages: expensed and capitalized. This is a unique context because the Korean Accounting 
Standards allow capitalization of R\&D as long as the investment has high economic feasibility, which is different from the stance of the U.S. Generally Accepted Accounting Principles (GAAP). Second, the Korean market is suitable for examining the agency problem driven by the wedge because it has the unique corporate governance structures of pyramidal and circular shareholdings. In addition, KFTC publicly discloses detailed information that can be used to calculate the cash flow rights and control rights of chaebols.

When the wedge is high, the results show that expensed R\&D is significantly and negatively related to firm value, while capitalized $R \& D$ does not show a significant relationship to firm value. This implies that suboptimal R\&D decisions are made when the wedge is high, and in particular, that investment behavior in the pursuit of the controlling shareholders' private benefits is common in expensed $R \& D$, for which the investment targets and investment projects can be discretionally determined by the manager.

In contrast, when the wedge is low, expensed R\&D does not show any significant relation to firm value and capitalized R\&D shows a significant and positive relation to firm value. In essence, we find one cause of no significant relationship between R\&D and firm value in previous studies. That is because they did not divide R\&D activities by different stages (expensed vs. capitalized), and expensed $R \& D$ is more prominent in the investment targets they analyzed. In the robustness analyses, the results remain qualitatively the same when we measure the wedge with other methods. Furthermore, we execute propensity score matching (PSM) to address potential endogeneity in the tests, and find the results are robust, confirming the main results.

This study makes several distinctive contributions. First, we confirm the importance of the wedge as a cause of the inconsistent positive relation between $R \& D$ and firm value that previous studies report. To the best of our knowledge, no previous study has investigated how the wedge triggers suboptimal $R \& D$. This study provides evidence that optimal R\&D decisions are not made when the wedge is high. Second, this study extends prior studies on the wedge related to a tunneling channel of controlling shareholders that reduces firm value by identifying $R \& D$ as a means of pursuing private benefits, especially expensed R\&D. Third, this study presents R\&D policy-related implications. Although R\&D is essential for sustainable economic growth, investors and regulators should pay attention to the initial stage of R\&D in firms with high wedges.

\section{Theory and Hypotheses}

\subsection{Accounting Standards for RED}

South Korea adopted the International Financial Reporting Standards (IFRS) in 2011. According to IFRS, R\&D costs are classified into two stages: research and development (IAS 38). The research stage includes costs for basic research conducted in the early stage of $R \& D$ activities and review of investment alternatives. The development stage includes costs for investment targets at the final stage, immediately before commercialization.

The research stage activities presented in IAS 38 (Intangible Assets) are: activities to (1) attain new knowledge; (2) search, evaluate, select, and apply research findings or other knowledge; (3) search for alternatives for materials, equipment, products, systems, or services; and (4) propose, design, evaluate, and select from among various alternatives for new or improved materials, equipment, products, systems, or services. The development stage is defined as activities to (1) design, fabricate, and test prototypes and models before production or use; (2) design tools, jigs, casts, and molds related to new technologies; (3) design, construct, and operate a small test factory not for commercial production; and (4) design, fabricate, and test the selected plan for new or improved materials, equipment, products, processes, systems, or services.

The costs in the research stage are fully expensed and the costs in the development stage are capitalized for the parts proved economically feasible, otherwise expensed. To prove economic feasibility, all of the following six requirements should be satisfied (IAS 38): (1) the technological 
feasibility of completing the asset to use or sell the intangible asset; (2) the intention of the firm to use or sell the intangible asset; (3) the ability of the firm to use or sell the intangible asset; (4) the existence of a market for trading the output of intangible assets or the intangible asset itself, or if the intangible assets will be used in the firm, the usefulness; (5) the possibility to obtain the technical and financial resources required to complete the development of the intangible assets and to sell or use them; and (6) the ability of the firm to reliably measure intangible asset-related expenditures incurred in the development process.

Therefore, expensed $R \& D$ and capitalized $R \& D$ have completely different natures, investment decision processes, and impact on financial statements. South Korea has applied such an R\&D accounting treatment since 1998, in accordance with the Korean Generally Accepted Accounting Principles (K-GAAP), and R\&D accounting treatment under K-GAAP is aligned with IFRS.

Unlike IFRS, U.S. GAAP takes a relatively more conservative approach. Specifically, the Financial Accounting Standards Board (FASB) considers R\&D expenses to involve high uncertainty of future performance and requires them to be treated as expenses for either the research or development stage. Thus, unlike firms that apply U.S. GAAP, Korean firms provide diverse information on R\&D that can enable multilateral studies to be conducted [9]. Studies conducted with US firms have indicated that $R \& D$ investments increase the volatility of future profits because R\&D investments involve higher future uncertainty than investments in tangible assets [27]. In studies conducted with Korean firms, however, capitalized R\&D and expenditures on tangible assets show no significant difference in their effects on future variability. The results indicate that Korean firms rationally divide research costs and development costs depending on the uncertainty of future profits.

\subsection{Literature Review}

\subsubsection{R\&D-Related Literature}

A number of studies have examined R\&D, which serves as a critical means of sustainable firm growth and the central force of firm value creation. Prior studies on R\&D can be classified into two categories: determinants of R\&D decisions and the effects of R\&D on R\&D-attributable performance.

Prior studies on the determinants of R\&D decisions can be classified as examining either financial or nonfinancial determinants. Studies on the financial determinants of R\&D have considered factors such as debt ratio, R\&D investments of the previous year, and growth rate (e.g., [28]). Bhagat and Welch [28] examine whether a firm's stock returns, operating cash flows, debt structure, and the tax environment have differential impacts on R\&D expenditures in the U.S., Canadian, British, European, and Japanese firms for the period 1985-1990. They find that there is a positive relation between stock returns with a two-year lag and R\&D expenditures in all countries. Operating cash flow does not show a significant relationship with future $R \& D$ expenditures. Lastly, the income tax coefficients are negative (positive) in the U.S. (Japan). In relation to nonfinancial determinants, studies have examined the impact of tax policies, the presence of a high technology (high tech) industry, market concentration, and market shares as determinants of R\&D (e.g., [29]).

Several studies have examined the influence of corporate governance structures on $R \& D[30,31]$. Bushee [30] shows that firms with dominant institutional ownership use momentum-trading strategies to reduce $R \& D$ investment in order to meet the short-term oriented performance expectations of institutional investors. On the other hand, institutional investors focused on long-term value play a monitoring role, restraining managerial incentives to adjust earnings to meet short-term oriented performance by reducing R\&D investment when they have majority ownership of the firm. Dechow et al. [31] find that CEOs in their last years in office reduce R\&D expenditures as a way of managing discretionary investments to improve short-term earnings performance. However, CEO stock ownership mitigates the reduction in $R \& D$. Thus, there is no evidence that the reduction in $R \& D$ is associated with poor firm performance or managing discretionary investment expenditures. 
A number of studies have examined the effects of R\&D on firm performance [5-8,23-26]. For instance, Sougiannis [5] finds a positive influence of $R \& D$ on reported earnings when there are differences in the industry-by-industry estimation of the earnings model in a panel data setting. Lev and Sougiannis [6] confirm that $R \& D$ yields positive and persistent influence over subsequent earnings for at least five to nine years. Aboody and Lev [25] find that there is a positive association between R\&D software capitalization and Tobin's Q. In a similar vein, Bublitz and Ettredge [23] and Chan et al. [24] show that R\&D has a positive impact on cumulative abnormal stock returns or share prices. However, Callen and Morel [8] report that a positive and significant relationship between R\&D and firm market value manifests in not more than 25\% of their sample from the period 1962 to 1996 with 6819 firm-year observations of 284 firms. This study investigates the value relevance of R\&D using an earnings-based time series valuation model. The results show that there is a weak support for the value relevance of R\&D market value, which contradicts the results using the cross-sectional and fixed effects panel models. Lastly, Han and Manry [9] examine the value relevance of expensed and capitalized R\&D and find that there is a positive association between capitalized R\&D and stock prices using the Ohlson equity-valuation model based on a sample of Korean firms from 1988 to 1998. Specifically, they identify that the capitalization of $R \& D$ is appropriate because investors perceive the capitalized R\&D represent greater future economic benefits.

There has been mixed evidence on the relationship between $R \& D$ and firm valuation or firm performance. This has triggered active research on moderators of the positive or negative relationship between $R \& D$ and firm performance, such as the moderating role of financial conditions. Diverse research has sought to find causes of inefficient investment conditions (e.g., [32-35]). Prior studies report that suboptimal R\&D brings forth economic burdens and decreases firms' competitiveness in the market in the long term.

For example, Franzen and Radhakrishnan [33] examine whether the value relevance of R\&D for loss firms extend to profit firms, using the residual-income valuation model. They find that earnings of profit firms contain the future benefits of R\&D; however, earnings of loss firms do not contain such information. Li and Hwang [34] report that there is a positive effect of R\&D on reported earnings only for highly profitable firms. Ciftci and Cready [35] find that the association between R\&D and future R\&D-attributable earnings depends on firm size. A number of studies have researched moderating effects on $R \& D$, but no prior research has examined the moderating effect of corporate governance mechanisms on $R \& D$ and firm performance. We expect that corporate governance plays a vital role in the relation between $R \& D$-attributable performance and efficient investment decisions [36].

\subsubsection{Control-Ownership Wedge-Related Literature}

Corporate ownership structure in Korea is unique because controlling shareholders enjoy substantial controlling power over affiliates that belong to large business groups. Controlling shareholders use indirect controls over the entire group through pyramidal and cross-shareholdings ownership amongst affiliates $[10,11,36]$. In other words, controlling shareholders have control over the group with a relatively small portion of cash flow rights through the circular ownership structure associated with affiliates. Such a phenomenon creates a divergence of cash flow rights (actual ownership by controlling shareholders based on firm cash flow), and control rights (including indirect ownership by controlling shareholders via cross or circular shareholdings with affiliates or relatives), known as the control-ownership wedge or simply the wedge. The wedge leads to an agency problem between controlling shareholders and minority shareholders [13]. Although the majority of research on the wedge has taken samples from emerging markets, past work has also shown evidence that the wedge manifests in developed markets [12-15].

Prior studies present evidence that firm performance or valuation decreases as the wedge increases [37-39]. For example, Lins [37] finds that firm value is lower when a management group's control rights exceed its cash flow rights. In contrast, a large non-management control rights blockholdings is positively associated with firm value. Both of these effects are more pronounced in 
countries with low shareholder protection. When controlling shareholders in an environment with a high wedge expropriate control from minority shareholders in order to extract private benefits, the firm value subsequently decreases. As the control rights of the controlling shareholders exceed their cash flow rights, the controlling shareholders become entrenched and exhibit opportunistic behavior to pursue private benefits [40].

According to Fan and Wong [41], an entrenchment problem arises when dominant controlling shareholders maximize their private benefits at the expense of minority shareholders when controlling shareholders are not challenged by an internal monitoring mechanism, such as a board of directors, in the context of the controlling shareholders-minority shareholder agency structure. In addition, they show that the controlling shareholders in firms with a high wedge have greater incentives to make decisions that harm minority shareholders.

Bertrand et al. [42] and Bae et al. [11] find direct evidence of the transfer of resources from minority shareholders to controlling shareholders in order to attain the controlling shareholders' private benefits, which is known as tunneling, the transfer of resources such as assets or profits that would be siphoned from the firm to extract private benefits of the controlling shareholders, which results in wealth transfers from minority shareholders to controlling shareholders [43].

Recent studies have extended prior studies on the negative impact of the wedge on firm value by examining the tunneling channel of controlling shareholders at firms with high wedges. Tunneling may take many forms, including transferring of assets, product/service transactions with related parties, excessive executive compensation, debt guarantees, and expropriation of private benefits by the controlling shareholders during merger activities with affiliates, acquirers, or acquirees [11,16,17]. Kahle and Shastri [17] examine the characteristics and the effects of loans made to executives for stock purchase, option exercise, and relocation. Their results indicate that the amounts of loans made to executives in purchasing stock or exercising options are larger than relocation loans, and carry higher interest rates. Further, the results show that managers with low ownership are more likely to receive stock purchase loans, and managers with high ownership receive greater option exercise loans and higher cash compensation.

This study explores the association between $R \& D$ and firm value in the context of high wedges and the incentive to extract private benefits. In other words, this study examines whether R\&D may be the tunneling mechanism for controlling shareholders to extract private benefits, which ultimately reduces firm value.

Masulis et al. [18] confirm that a high wedge decreases the market value of cash holdings among a sample of U.S. dual-class firms. The results imply that investors expect CEOs in firms with high wedges to tend to engage in perquisite consumption, empire building activities, excessive compensation, and sustaining unprofitable projects, reducing the value of cash holdings. In addition, capital expenditures for asset acquisitions or capital investments are negatively associated with firm value as the wedge increases. The results imply that investors perceive firms with high wedges as more likely to make suboptimal investment decisions to extract private benefits for controlling shareholders rather than to increase shareholders' value.

Similar to Masulis et al. [18], Belkhir et al. [19] find that a high wedge decreases the value of cash holdings in publicly listed French firms. The results imply that managers extract private benefits, squander cash on empire building, or invest in projects with negative NPV in the absence of good investment opportunities. Jiang et al. [20] find a negative relation between a high wedge and investment-q sensitivity based on East Asian countries such as Hong Kong, India, Japan, South Korea, and Malaysia. Controlling shareholders in firms with high wedges extract private benefits, and they are less sensitive to stock market reactions. Consequently, a high wedge results in inefficient resource allocations and leads to suboptimal investment decisions. In other words, a wedge discourages optimal investment decisions based on capital market information. Furthermore, a wedge deteriorates the capital market function, which promotes efficient resource allocation. 
Goh et al. [44] confirm that a wedge is positively associated with overinvestment and that there is a nonmonotonic relation between the wedge and overinvestment. The results imply that controlling shareholders make inefficient investment decisions within a certain range of wedge when the marginal benefits of extracting private benefits exceed the marginal costs. This study differentiates itself from prior studies on the wedge by focusing on R\&D, also dividing it into expensed and capitalized R\&D as channels of investments with distinctive natures.

This study differentiates itself from prior studies by identifying R\&D as a means of controlling shareholders' tunneling channel when a wedge is high. Further, we examine evidence that R\&D has a differential impact on firm value by dividing R\&D activities in two different stages: expensed and capitalized.

\subsection{Hypotheses Development}

The agency conflicts, according to the traditional agency theory, suggest information asymmetry issues such as moral hazard or adverse selection in the principal-agent relationships [45]. Another type of the agency conflict is between the controlling shareholders and the minority shareholders [13,46]. The conflicts of interests between controlling shareholders and minority shareholders follow through to expropriate wealth from minority shareholders to maximize controlling shareholders' interest. On the other hand, according to the convergence of interest hypothesis, controlling shareholders make the optimal decisions to increase firm value, which enhances the interest of minority shareholders. However, in reality, as the divergence of cash flow rights and control rights increases, the agency conflict between controlling shareholders and minority shareholders aggravates because controlling shareholders are more likely to pursue private benefits [47,48].

Control rights provide the right to shareholders to participate in the firm's decision-making process through voting, depending on the degree of indirect or direct controls over the entire number of shares. Cash flow rights (or ownership rights) are measured as a ratio of the number of shares that can be directly controlled and interpreted as the right to claim the profits that the firm generates in the form of dividends. The divergence between control rights and cash flow rights, also known as the wedge, manifests when a firm has a pyramid structure and circular shareholdings. In this case, entire subsidiaries are controlled by controlling shareholders who have small ownership rights but large control rights [10-12]. Controlling shareholders with large control rights enjoy the firm's profits through private consumption at limited costs, depending on the number of their shares in the firm. Therefore, as the wedge increases, an agency problem between controlling shareholders and minority shareholders increases because of an imbalance between the risks resulting from the controlling shareholders' decisions and the private benefits vested to the controlling shareholders [13].

Controlling shareholders in firms with high wedges make investments that have high risk and are likely to have favorable outcomes for private misappropriation of resources. This is because controlling shareholders will bear their investment losses in terms of their cash flow rights rather than their control rights. In addition, such controlling shareholders may have incentives to use the firm's resources privately instead of maximizing investment outcomes for shareholders. Thus, we often observe suboptimal investment decisions when the wedge is high [18,20-22].

In addition, high wedges may result in suboptimal investments because the monitoring function of the firm is weakened [11,49]. When controlling shareholders have greater control rights than cash flow rights, they are entrenched to easily pursue opportunistic benefits [40]. When controlling shareholders have strong power over the decision-making process of the board of directors, it weakens the monitoring function of the board of directors. This ultimately results in the entrenchment effect on the firm, which maximizes private wealth of the controlling shareholders at the cost of minority shareholders' wealth [41]. As the wedge increases, controlling shareholders care less about capital market investors' responses, which leads to a decrease in investment-q sensitivity, so that optimal investments cannot be made [20]. 
Thus, when the wedge is high, suboptimal investment decisions lead $R \& D$ to reduce firm value, and the relevant effects may differ depending on the R\&D stage. This is because the incentives and processes of investment decisions are different in the early, middle, and final stages of R\&D investment. In the case of expensed R\&D in the early or middle stages, the investment targets are often not fixed because expensed $R \& D$ is intended to obtain diverse knowledge or search for new alternatives. Therefore, controlling shareholders can easily misuse expensed $R \& D$ as a channel to pursue their private benefits (e.g., through perquisite consumption, excessive compensation, and non-arm's length transactions). For instance, in the expensed $R \& D$ stage, expenditures can be made in investments that are irrelevant to the current business, and such investments will enable transactions with controlling shareholders' affiliated parties with whom normal transactions cannot be easily made. The firm's resources can be extracted through transactions that support related parties within the conglomerate.

On one hand, when the wedge is high, controlling shareholders' empire-building and optimism may lead to a negative relationship between expensed R\&D and firm value. Empire-building theory suggests that increased firm size grants larger benefits and rights to controlling shareholders, which leads to future investment decisions despite negative NPV as long as the firm size increases [50,51]. Expensed R\&D investments are made in the stage in which expenses are spent to review new investment alternatives that consider different directions from that of the existing business (e.g., the start-up of new projects or the expansion of a laboratory) in order to increase firm size. In addition, managers at dual-class firms with high wedges are known to prefer business diversification [52] and expensed R\&D may be a channel to add new business as part of business diversification. The optimistic behavior of controlling shareholders in firms with high wedges is known to invest in low-NPV projects and waste cash resources on excessive perquisites [50]. That is, when the wedge is high, expensed R\&D may be deployed to pursue private benefits leading to the reduction of firm value. Therefore, the following hypothesis is set for expensed R\&D.

Hypothesis 1-1. When the control-ownership wedge is high, expensed RED is negatively related to firm value.

Capitalized R\&D refers to investments with high economic feasibility that have clear investment targets that may be commercialized soon. Thus, controlling shareholders do not have much discretionary power in decision making for investment targets, investment accounts, and expenditure scales over capitalized R\&D. When the wedge is high, capitalized R\&D cannot be easily utilized as a channel to pursue private benefits like perquisite consumption, excessive compensation, and non-arm's length transactions. Therefore, the effect of capitalized $R \& D$ on firm value in the presence of a high wedge may be different from that of expensed R\&D. Previous studies have examined the relationship between value relevance (or future profit) and expensed $R \& D$ or capitalized $R \& D$ respectively and reported that the latter is more closely related with value relevance and future profits $[9,53]$.

Therefore, even if the wedge is high, capitalized $R \& D$ may have a positive impact on firm value. However, when the wedge is high, the suboptimal investment disposition may have a partial impact on capitalized R\&D. Thus, we construct the following hypothesis in null form.

Hypothesis 1-2. When the control-ownership wedge is high, capitalized RED is not related to firm value.

Although the majority of prior studies document that R\&D has positive effects on firm value $[5-7,20,23,25,26]$, there is a lack of consistency in the positive relation between $R \& D$ investments and firm value. Therefore, when the wedge is low, we conjecture that controlling shareholders have less opportunity to pursue private benefits. In this case, both expensed and capitalized R\&D enhances firm value. However, we expect that expensed $R \& D$ in the early R\&D stage has low economic feasibility and immaterial impact on firm value. Thus, we set the null hypothesis for the effect of expensed R\&D on firm value.

Hypothesis 2-1. When the control-ownership wedge is low, expensed RED is not related to firm value. 
Hypothesis 2-2. When the control-ownership wedge is low, capitalized RED is positively related to firm value.

\section{Research Design and Sample Selection}

\subsection{Sample Selection}

The samples in this study include publicly listed chaebol firms in Korea from 2001 through 2015. We exclude financial firms that do not have comparable financial statements and firms with insufficient financial data or control-ownership wedge data. The financial data and stock price data are from Data Guide provided by FnGuide, and transactions with affiliated parties are from Kis-value. These Korean databases are similar to COMPUSTAT and CRSP that provide data on Korean listed companies.

The main variable of interest, wedge data on firms classified as large business groups (chaebols), is publicly available from KFTC. Chaebols are subject to the Monopoly Regulation and Fair Trade Act and have total assets not less than two trillion won. Their mutual investments within the business group are restricted and the KFTC officially announces the business group list, affiliates, and direct and indirect share ratios. KFTC has disclosed data on chaebols on its website since 2000. In this study, we manually calculate the wedge based on the collected control-ownership data from open source (http://groupopni.ftc.go.kr). KFTC disclose wedge data restricted to chaebol firms, and this study excludes 5106 non-chaebol firm-year samples. We then exclude firms without the wedge data and arrive at the final sample of 1342 firm-years. The detailed sample selection process is given in Panel A of Table 1.

Table 1. Sample Selection and Distribution.

\begin{tabular}{|c|c|}
\hline \multicolumn{2}{|l|}{ Panel A. Sample Selection Criteria } \\
\hline Sample Selection Process & Sample Size \\
\hline Public (KSE) firm-years for the period of FY 2001-2015 & 9352 \\
\hline (Less) Firms with insufficient financial data & 2904 \\
\hline (Less) Firms with insufficient wedge data & 5106 \\
\hline Final sample size used for testing the hypotheses & 1342 \\
\hline \multicolumn{2}{|l|}{ Panel B. Samples by Industry } \\
\hline Industry & Sample Size \\
\hline Food production & 49 \\
\hline Beverage manufacturing & 12 \\
\hline Tobacco industry & 7 \\
\hline Textile products, except clothing & 12 \\
\hline Apparel, clothing accessories and fur products & 3 \\
\hline Leather, bags and footwear & 2 \\
\hline Wood and wood products; Furniture exclusion & 6 \\
\hline Pulp, paper and paper products & 8 \\
\hline Briquette and oil refining products & 2 \\
\hline Chemical, except medicines & 172 \\
\hline Medical materials and pharmaceuticals & 11 \\
\hline Rubber and plastic products & 27 \\
\hline Non-metallic mineral products & 47 \\
\hline Primary metals & 119 \\
\hline Metalworking products, except machinery and furniture & 10 \\
\hline Electronic components, computers, and communication equipment & 97 \\
\hline Medical, precision, optics and watch & 6 \\
\hline Electrical equipment & 46 \\
\hline Other machinery and equipment & 64 \\
\hline Automobile and trailer manufacturing & 46 \\
\hline
\end{tabular}


Table 1. Cont.

\begin{tabular}{cc}
\hline Panel B. Samples by Industry & \\
Industry & Sample Size \\
\hline Other transportation equipment & 65 \\
Furniture manufacturing & 1 \\
Electricity, gas, steam, and air conditioning supply business & 41 \\
Total construction business & 149 \\
Professional work & 1 \\
Wholesale and commodity brokerage & 55 \\
Retailing; Excluding cars & 53 \\
Water transportation & 2 \\
Air transportation & 14 \\
Westaurants and pubs & 8 \\
publishing business & 1 \\
Drehouse and transportation related service & 14 \\
Broduction and distribution of video and audio recordings & 5 \\
Mail and communication & 3 \\
Computer programming, system integration and management & 35 \\
Information service industry & 26 \\
Professional Services & 5 \\
Construction, engineering and other technical services & 76 \\
Business Support Service & 17 \\
Education service industry & 17 \\
\hline Total sum & 8 \\
\hline
\end{tabular}

\subsection{Measuring Wedges}

Korean chaebols are controlled by controlling shareholders who hold influential equities in the large business groups. The wedge is generally defined as the disparity between the control rights and cash flow rights. The control rights are the sum of the voting rights controlled (not owned) by a majority owner and his or her connected parties, such as relatives, senior managers, and nonprofit organizations. The cash flow rights are the shares held or owned by a controlling owner. We measure the cash flow rights by incorporating both direct holdings and indirect holdings through affiliates [12,16,49].

We differentiate this study from prior studies in two aspects. First, we measure majority shareholders' holding equity portions by employing indirect cash flow rights. While most prior studies use the direct cash flow rights, we use the indirect cash flow rights because indirect cash flow rights capture a whole picture of equity share matrix for all the affiliated firms that belong to on chaebol group. Equation (1) shows the computation for indirect cash flow rights. For a chaebol with $\mathrm{N}$ affiliated firms, DirectCF $F_{i}$ captures a direct equity holding of a majority shareholder and his/her related parties over an affiliated firm $i$, while $C F_{j} \times A$ ffiliate $C F_{j i}$ captures an indirect ownership portion over firm $i$. Further, $A$ ffiliate $C F_{j} i$ is a direct equity portion of an affiliated firm $j$ over another affiliated firm, and $C F_{j}$ is the total ownership portion of majority owner and his/her related parties over an affiliated firm $j$.

$$
\text { Cashflowrights }\left(C F_{i}\right)={\operatorname{Direct} C F_{i}}_{i} \sum_{j=1}^{N} C F \times A f f i l a i t e C F_{i j}(i=1,2, \ldots, \mathrm{N}),
$$

We also differentiate this study from prior studies by adopting two kinds of wedge measures. We employ the control-ownership wedge (wedge1), which is denoted as the disparity between control and cash flow rights [10,39], as well as a wedge defined by the ratio of control rights and cash flow rights (wedge2) from Lins [37]. These measures are as follow in Equations (2) and (3), respectively.

$$
\text { Wedge } 1_{t}=\text { Votingrights }_{t}-\text { Cash flowrights }{ }_{t}
$$




$$
\text { Wedge }_{t}=\frac{1+\text { Votingrights }_{t}}{1+\text { Cashflowrights }_{t}}
$$

\subsection{Firm Clustered Regression Model}

We apply clustered linear regression models to examine our main hypotheses as in research model (1). We adopt the clustered algorithm to increase the accuracy of classical linear regressions with some clustering in the multiple regression. We use firm clustered method, which partition samples by firm characteristics.

$$
\begin{aligned}
& q=\alpha_{0}+\beta_{1} r 1(\text { or } r 2, r 3)+\beta_{2} \text { size }+\beta_{3} \text { lev }+\beta_{4} \text { roa }+\beta_{5} \text { cfo }+\beta_{6} \text { salesgrow }+\beta_{7} \text { advertise } \\
& +\beta_{8} \text { capex }+ \text { year fixed effects }+ \text { firm fixed effects }+\varepsilon
\end{aligned}
$$

where $r 1=$ expensed R\&D/total sales; $r 2=$ capitalized R\&D/total sales; $r 3=\mathrm{R} \& \mathrm{D}$ cost/total sales; $q=$ Tobin's $Q$, which is equal to (market value of equity + book value of debt)/total asset; wedge1 = control-ownership wedge of the controlling shareholders computed as (voting right - cash flow right); wedge $2=$ control-ownership ratio of the controlling shareholders computed as $(1+$ voting right $) /(1+$ cash flow right $)$; size = natural logarithm of market capitalization; $l e v=$ total liabilities/total equity; $r o a=$ net income/total asset; $c f o=$ operating cash flow/total asset; salesgrow $=$ growth ratio, which is equal to (sales - lagged sales)/lagged sales; advertise $=$ advertising cost/total sales; capex $=$ capital expenditure/total sales.

Model (1) identifies the combined effects of the wedge and R\&D on Tobin's Q. We decompose total R\&D costs $(r 3)$ into expensed R\&D ( $r 1)$ and capitalized R\&D ( $r 2)$. Following Lang and Stulz [54] and Allayannis and Weston [55], we control other effects on Tobin's Q. Thus, firm size (size), profitability (roa), investment to grow (capex), and leverage (lev) proxy the other factors. Furthermore, growth ratio (salesgrow) represents future potential and cash flows ( $c f o$ ) to control the cash liquidities to finance for future growth [56]. Finally, we include a year fixed effect and firm fixed effects to control unobservable factors of both seasonal and individual characteristics.

\section{Results}

\subsection{Descriptive Statistics}

Table 2 summarizes the descriptive statistics of all the variables of this study. The dependent variable, Tobin's $Q(q)$, shows a median value of 1.005 , representing approximately $101 \%$ of market value and debts to total assets, on average. We have three main independent variables: expensed $\mathrm{R} \& \mathrm{D}(r 1)$, capitalized R\&D ( $r 2)$, and total R\&D costs $(r 3)$. The mean values of these variables are $0.023,0.003$, and 0.026 , respectively. This shows that most firms invest more than seven times as much in the expensed R\&D phase than the capitalized R\&D final phase. Additionally, $26 \%$ of the total $R \& D$ investments is consumed for future growth. The control-ownership wedge (wedge1) indicates 0.179, which shows that controlling shareholders excessively control the affiliates and their minority shareholders at almost $18 \%$. Such phenomena have been conspicuous among Asian markets, especially Korean conglomerate groups.

Table 2 also shows summaries of control variables. The average of size, roa, and $c f o$ is $20.343,0.038$, and 0.072 , which are similar to the results of prior studies. The mean value of $l e v$ is 0.505 , representing Korean chaebols' higher dependencies on debt financing. The annual average sales growth ratio (salesgrow) is 0.088 , the expenditure on advertisement is 0.007 , and capital expenditure to total sales is 0.025 . 
Table 2. Descriptive Statistics $(\mathrm{N}=1342)$.

\begin{tabular}{cccccc}
\hline & Mean & Std & Min & Median & Max \\
\hline$r 1$ & 0.023 & 0.063 & 0.000 & 0.007 & 0.545 \\
$r 2$ & 0.003 & 0.009 & 0.000 & 0.000 & 0.066 \\
$r 3$ & 0.026 & 0.064 & 0.000 & 0.009 & 0.545 \\
$q$ & 1.179 & 0.584 & 0.406 & 1.005 & 3.829 \\
wedge1 & 0.174 & 0.159 & 0.000 & 0.162 & 0.612 \\
wedge2 & 1.152 & 0.144 & 1.000 & 1.130 & 1.570 \\
size & 20.343 & 1.902 & 16.455 & 20.351 & 24.658 \\
lev & 0.505 & 0.191 & 0.081 & 0.525 & 0.952 \\
roa & 0.038 & 0.076 & -0.262 & 0.040 & 0.222 \\
cfo & 0.072 & 0.089 & -0.164 & 0.064 & 0.337 \\
salesgrow & 0.088 & 0.236 & -0.487 & 0.065 & 1.279 \\
advertise & 0.007 & 0.017 & 0.000 & 0.001 & 0.108 \\
capex & 0.025 & 0.111 & -0.205 & 0.028 & 0.393 \\
\hline
\end{tabular}

Where $\boldsymbol{r} \mathbf{1}=$ expensed R\&D/total sales; $\boldsymbol{r} \mathbf{2}=$ capitalized R\&D/total sales; $\boldsymbol{r} \mathbf{3}=\mathrm{R} \& \mathrm{D}$ cost/total sales; $\boldsymbol{q}=$ Tobin's $\mathrm{Q}$, which is equal to (market value of equity + book value of debt)/total asset; wedge 1 = control-ownership wedge of the controlling shareholders computed as (voting right - cash flow right); wedge 2 = control-ownership ratio of the controlling shareholders computed as $(1+$ voting right $) /(1+$ cash flow right $) ;$ size $=$ natural logarithm of market capitalization; lev = total liabilities/total equity; roa $=$ net income/total asset; $c f o=$ operating cash flow/total asset; salesgrow $=$ growth ratio, which is equal to (sales - lagged sales)/lagged sales; advertise $=$ advertising cost/total sales; capex $=$ capital expenditure/total sales.

\subsection{Correlation Results}

Table 3 shows the Pearson correlation results below between variables applied in multivariate tests. Based on the Pearson correlation results, the dependent variable $q$ positively correlated with the independent variables for $r 1$ ( $p$-value $=0.099), r 2(p$-value $<0.0001)$, and $r 3(p$-value $=0.007)$. The results for main variable wedge and q show no significant associations as in wedge1 ( $p$-value $=$ $0.532)$, wedge2 ( $p$-value $=0.651)$ in these univariate results. Controls show positive coefficients to Tobin's $\mathrm{Q}(q)$ for size 0.331 ( $p$-value $<0.0001)$, roa $0.227(<0.0001)$, cfo $0.250(<0.0001)$, salesgrow $0.092(0.001)$, and advertise $0.267(<0.0001)$, or negative coefficients for lev $-0.069(0.012)$, which are consistent with prior studies. However, we do not find any significant relations between $q$ and capex $(\mathrm{t}$-value $=0.016$, $p$-value $=0.565)$. In other words, the market values of firms increase with larger firm size, net profit, operating cash flow, and sales growth, but with less leverage. 
Table 3. Correlation Matrix ( $\mathrm{N}=1342)$.

\begin{tabular}{|c|c|c|c|c|c|c|c|c|c|c|c|c|c|}
\hline & $r 1$ & $r 2$ & $r 3$ & $q$ & wedge1 & wedge2 & size & lev & roa & cfo & salesgrow & advertise & capex \\
\hline \multirow[t]{2}{*}{$r 1$} & 1.000 & 0.187 & 0.987 & 15 & 0 & 0 & 36 & -0.234 & -0.067 & -0.053 & 0.033 & 0.157 & -0.050 \\
\hline & & $<0.0$ & $<0.0001$ & 99 & & & 0.184 & $<0.0001$ & 0.014 & & 0.226 & 001 & \\
\hline \multirow{2}{*}{$-\overline{r 2}$} & $\overline{0} . \overline{0} \overline{3}$ & $-\overline{1.000}$ & $-0 . \overline{3} \overline{6}$ & $0.1 \overline{8} 0$ & $\overline{0.029}$ & $\overline{0} . \overline{0} \overline{2}$ & $-0.0 \overline{07}$ & $-\overline{0} . \overline{0} 1 \overline{8}-$ & $\overline{-0.1 \overline{4}} \overline{1}$ & $\overline{-0 . \overline{01} \overline{9}}$ & $0.0 \overline{1} 8$ & $-\overline{0} . \overline{0} 3 \overline{7}$ & $-0 . \overline{0} \overline{4}$ \\
\hline & 0.007 & & $<0.0001$ & $<0.0001$ & 0.295 & 0.657 & 0.797 & 0.500 & $<0.0001$ & 0.478 & 0.518 & 0.179 & 0.217 \\
\hline \multirow{2}{*}{$--\overline{r 3}--$} & $\overline{0} \overline{9} \overline{30}-$ & $\overline{0.2 \overline{98}}-$ & 1.000 & $0.0 \overline{7} \overline{-}-$ & $-\overline{0} . \overline{0} 8 \overline{2}$ & $-0 . \overline{094}$ & $\overline{0} . \overline{0} 3 \overline{0}$ & $-\overline{-}-\overline{0} 2 \overline{2} 4^{-}$ & $-\overline{0.09} \overline{2}$ & $=\overline{0} . \overline{05} \overline{5}$ & $\overline{0.0 \overline{3}} \overline{-}$ & $-\overline{0.152}$ & $-\overline{-0} \overline{0} \overline{6}^{-}$ \\
\hline & $<0.0001$ & $<0.0001$ & & 0.007 & 0.003 & 0.001 & 0.268 & $<0.0001$ & 0.001 & 0.044 & 0.178 & $<0.0001$ & 0.040 \\
\hline \multirow{2}{*}{$--\bar{q}^{-}$} & $\overline{0} . \overline{2} 2 \overline{4}$ & $\overline{0.155^{-}}$ & $-\overline{0.255}{ }^{-}$ & $\overline{1.000}-$ & $\overline{0.01 \overline{7}}$ & $\overline{-0.0 \overline{12}}$ & $\overline{0} . \overline{3} 3 \overline{1}$ & $-\overline{-0.069}$ & $\overline{0} \overline{2} 2 \overline{2} \overline{-}$ & $-\overline{0.250}$ & $\overline{0.09} 2^{-}$ & $\overline{0} . \overline{26} \overline{7}$ & 0.016 \\
\hline & $<0.0001$ & $<0.0001$ & $<0.0001$ & & 0.532 & 0.651 & $<0.0001$ & 0.012 & $<0.0001$ & $<0.0001$ & 0.001 & $<0.0001$ & 0.565 \\
\hline \multirow{2}{*}{$\bar{w} \bar{e} \bar{d} g \bar{e} 1$} & $-\overline{-0.00 \overline{1}}{ }^{-}$ & $-\overline{0} \overline{0} \overline{4} \overline{-}$ & $\overline{0}-\overline{0} \overline{9} 9$ & $0.0 \overline{2} 6$ & 1.000 & $\overline{0} . \overline{9}$ & $-0 . \overline{19} \overline{7}^{-}$ & $\overline{0}$. & $\overline{0} \overline{0} \overline{6} 4$ & $-\overline{0.0} \overline{4} 4$ & 51 & $-\overline{0}$ & $-\overline{-0} \overline{0} \overline{17}$ \\
\hline & 0.977 & 0.111 & 0.746 & 0.347 & & $<0.0$ & $<0.0001$ & & & 0. & & & \\
\hline \multirow{2}{*}{$-\bar{w} e \bar{d} g \bar{e} 2$} & $-0.0 \overline{2} 2$ & $\overline{0.025}$ & ${ }^{-} \overline{0} . \overline{01} \overline{7}$ & $-\overline{0} . \overline{0} 0 \overline{5}$ & $\overline{0.9 \overline{9}} \overline{3}$ & $-\overline{1} . \overline{00} \overline{0}$ & $-0 . \overline{4} \overline{40}^{-}$ & & & & 0.052 & & $-0 . \overline{0} 24$ \\
\hline & 0.422 & 0.364 & 0.545 & 0.842 & $<0.0001$ & & $<0.0001$ & 0. & 0.059 & 0.472 & 0.057 & 0. & 0.389 \\
\hline \multirow[t]{2}{*}{ size } & $\overline{0} . \overline{2} 0 \overline{4}$ & $0 . \overline{150}$ & $0 . \overline{190}$ & $\overline{0.4 \overline{5}} \overline{7}$ & $-\overline{0} . \overline{1} 8 \overline{3}$ & $-\overline{-0} \overline{2} \overline{18}$ & $\overline{1} . \overline{0} 0 \overline{0}^{-}$ & $-0.0 \overline{7} 0$ & $\overline{0.3 \overline{13}}$ & $0 . \overline{2} \overline{4} 8$ & $0.0 \overline{7} 0$ & $\overline{0}$ & $\overline{0} . \overline{0} 6 \overline{6}$ \\
\hline & $<0.0001$ & $<0.0001$ & $<0.0001$ & $<0.0001$ & $<0.0001$ & $<0.0001$ & & 0.010 & $<0.0001$ & $<0.0001$ & 0.010 & $<0.0001$ & 0.016 \\
\hline \multirow[t]{2}{*}{$-{ }^{-} \overline{l e v}^{-}-$} & $-\overline{-0.1 \overline{5} 6}$ & $0 . \overline{153}{ }^{-}$ & ${ }^{-} \overline{0.13 \overline{3}}$ & $0.0 \overline{4}{ }^{-}$ & $\overline{0.068}$ & $-\overline{0} . \overline{06} \overline{5}$ & ${ }^{-}-0.056$ & $\overline{1} . \overline{0} \overline{0}$ & $-\overline{-} \overline{3} \overline{4} \overline{6}$ & ${ }^{-}-\overline{0} \overline{250}$ & $-\overline{0} . \overline{0} 4 \overline{3}$ & $-\overline{0} \overline{126}$ & $-\overline{-0.0 \overline{49}^{-}}$ \\
\hline & $<0.0001$ & $<0.0001$ & $<0.0001$ & 0.137 & 0.013 & 0.017 & 0.042 & & $<0.0001$ & $<0.0001$ & 0.118 & & 74 \\
\hline \multirow[t]{2}{*}{ roa } & $\overline{0} . \overline{0} 2 \overline{8}^{-}$ & $-\overline{0.0 \overline{4}} \overline{9}$ & $\overline{-0.005}$ & $\overline{0.32} \overline{2}$ & $\overline{0.102}$ & $\overline{0} . \overline{0} \overline{0}$ & $\overline{0} . \overline{3} 2 \overline{3}$ & $\overline{-0.3 \overline{8}} 2^{-}$ & $-\overline{1.000}-$ & $0.4 \overline{7} 2^{-}$ & $0 . \overline{2} 2$ & $-\overline{0} \overline{14} 0^{-}$ & $\overline{0} . \overline{17} \overline{7}$ \\
\hline & 0.300 & 0.070 & 0.856 & $<0.0001$ & 0.000 & 0.001 & $<0.0001$ & $<0.0001$ & & $<0.0001$ & $<0.0001$ & $<0.0001$ & $<0.0001$ \\
\hline \multirow[t]{2}{*}{$--\overline{c f f o}^{-}$} & $\overline{0} . \overline{0} 5 \overline{9}$ & $-\overline{0.014}$ & $-\overline{0.054}$ & $-\overline{0.22} \overline{4}^{-}$ & $\overline{0.08}$ & $\overline{0} . \overline{0}$ & $\overline{0} . \overline{2} 2 \overline{1}-$ & $-\overline{-0.276}$ & 0. & $1.000^{-}$ & $\overline{0.16 \overline{6}}$ & $-\overline{0 .}$ & $\overline{0} . \overline{2} 4 \overline{5}$ \\
\hline & 0.032 & 0.610 & 0.047 & $<0.0001$ & 0.001 & 0.017 & $<0.0001$ & $<0.0001$ & $<0.0001$ & & $<0.0001$ & $<0.0001$ & $<0.0001$ \\
\hline \multirow{2}{*}{$\overline{\text { salesgrow }}$} & $\overline{-0.00 \overline{4}}-$ & $\overline{-0.00} \overline{9}^{-}$ & $\overline{-0 . \overline{0} \overline{8}}$ & $\overline{0.139}$ & $\overline{0.10 \overline{3}}$ & $\overline{0} . \overline{1} 0 \overline{0}$ & $-\overline{0} . \overline{1} 1 \overline{4}-$ & $-\overline{-0.0 \overline{2} 1}$ & $-\overline{3} \overline{3} \overline{1}-$ & $\overline{0.1 \overline{9}} \overline{-}$ & $-\overline{1.00} 0^{-}$ & $-\overline{0.0 \overline{8}} \overline{-}$ & $-\overline{0} . \overline{0} 4 \overline{3}-$ \\
\hline & 0.896 & 0.743 & 0.514 & $<0.0001$ & 0.000 & 0.000 & $<0.0001$ & 0.450 & $<0.0001$ & $<.0001$ & & 0.000 & 0.115 \\
\hline \multirow[t]{2}{*}{ a a dvertise } & $\overline{0} . \overline{095}$ & $\overline{0} \overline{0} \overline{0} \overline{7}$ & $0.0 \overline{9} 2$ & $0 . \overline{18} \overline{3}$ & $\overline{0.004}$ & $-\overline{0} . \overline{0} 0 \overline{4}$ & $\overline{0} . \overline{3} 0 \overline{2}^{-}$ & $\overline{0} . \overline{0} 0 \overline{0}$ & $\overline{0} \overline{1} \overline{80} 0^{-}$ & $-\overline{0.1} \overline{4} 5^{-}$ & $\overline{0.022}$ & $\overline{1.000}$ & $\overline{0} . \overline{07} \overline{5}$ \\
\hline & 0.001 & 0.181 & 0.001 & $<0.0001$ & 0.876 & 0.874 & $<0.0001$ & 0.990 & $<0.0001$ & $<0.0001$ & 0.431 & & 0.006 \\
\hline \multirow[t]{2}{*}{ capex } & $\overline{0} . \overline{0} \overline{8}$ & $\overline{0.034}$ & $\overline{0.0 \overline{2} 4}$ & $\overline{0.1 \overline{2} 1}$ & $\overline{0.0 \overline{1}} \overline{0}$ & $-0 . \overline{0} \overline{2}$ & $\overline{0} . \overline{17} \overline{9}-$ & $-0.0 \overline{8} 7^{-}$ & $0 . \overline{210}$ & $-\overline{0.317^{-}}$ & 0.102 & & $\overline{1} . \overline{0} \overline{0}$ \\
\hline & 0.766 & 0.216 & 0.383 & $<0.0001$ & 0.704 & 0.931 & $<0.0001$ & 0.001 & $<0.0001$ & $<0.0001$ & 0.000 & $<0.0001$ & \\
\hline
\end{tabular}

Pearson correlation results are reported. $P$-values are presented in parentheses. See Table 2 for a definition of the variables. 


\subsection{The Effects of the Wedge on RED and Firm Value}

Table 4 shows the results of subsample analyses on the effects of the wedge on the relation between R\&D and firm value. Panel A shows that the samples of the wedge ratios are higher than the median wedge value of 0.162 , whereas panel B shows samples of the wedge that are lower than the median. We also append the results of comparing coefficient tests between two separate samples.

Consistent with the notion that R\&D is positively correlated to firm value [25], panel B shows positive associations between $r 2$ and $r 3$ with q, respectively, in low wedge subsamples. The positive coefficient of $r 2(13.055$, with $\mathrm{t}$-value $=2.900)$ confirms hypothesis $2-2$, which indicates that capitalized $R \& D$ investment under less wedge influence leads to fruitful returns as firm value increases.

Table 4. Valuation Effect of R\&D and the Wedge.

\begin{tabular}{|c|c|c|c|c|}
\hline \multirow[b]{2}{*}{ VARIABLES } & \multicolumn{2}{|c|}{$\begin{array}{c}\text { Panel A } \\
\text { High Wedge1 }\end{array}$} & \multicolumn{2}{|c|}{$\begin{array}{c}\text { Panel B } \\
\text { Low Wedge1 }\end{array}$} \\
\hline & $q$ & $q$ & $q$ & $q$ \\
\hline \multirow[t]{2}{*}{$r 1$} & & $-2.292^{* *}$ & & 0.222 \\
\hline & & $(-2.225)$ & & $(0.853)$ \\
\hline \multirow[t]{2}{*}{$r 2$} & & -0.558 & & $13.055^{* * *}$ \\
\hline & & $(-0.228)$ & & $(2.900)$ \\
\hline \multirow[t]{2}{*}{$r 3$} & $-1.930 * * *$ & & 0.633 * & \\
\hline & $(-2.666)$ & & (1.695) & \\
\hline \multirow[t]{2}{*}{ size } & $0.429 * * *$ & $0.427^{* * *}$ & $0.384^{* * * *}$ & $0.389 * * *$ \\
\hline & $(6.757)$ & $(6.748)$ & $(8.604)$ & $(9.018)$ \\
\hline \multirow[t]{2}{*}{ lev } & $0.814^{* * *}$ & $0.816^{* * *}$ & $1.111^{* * *}$ & $1.161^{* * *}$ \\
\hline & $(3.354)$ & $(3.345)$ & $(4.996)$ & $(5.274)$ \\
\hline \multirow{2}{*}{ roa } & -0.070 & -0.055 & 0.153 & 0.228 \\
\hline & $(0.202)$ & $(-0.160)$ & $(0.485)$ & $(0.843)$ \\
\hline \multirow[t]{2}{*}{$c f o$} & $0.667^{* * *}$ & $0.661^{* * *}$ & 0.367 & 0.364 \\
\hline & $(3.855)$ & $(3.831)$ & (1.596) & $(1.626)$ \\
\hline \multirow[t]{2}{*}{ salesgrow } & -0.028 & -0.029 & 0.041 & 0.039 \\
\hline & $(-0.379)$ & $(-0.390)$ & $(0.745)$ & $(0.715)$ \\
\hline \multirow[t]{2}{*}{ advertise } & -1.454 & -1.423 & 0.597 & 1.824 \\
\hline & $(-0.349)$ & $(-0.341)$ & $(0.334)$ & (1.137) \\
\hline \multirow[t]{2}{*}{ capex } & $-0.390^{* *}$ & $-0.381^{* *}$ & -0.123 & -0.163 \\
\hline & $(-2.274)$ & $(-2.211)$ & $(-0.602)$ & $(-0.718)$ \\
\hline \multirow[t]{2}{*}{ Constant } & $-7.581^{* * * *}$ & $-7.554^{* * *}$ & $-7.226^{* * *}$ & $-7.390^{* * *}$ \\
\hline & $(6.122)$ & $(-6.114)$ & $(-7.872)$ & $(-8.104)$ \\
\hline Observations & 671 & 671 & 671 & 671 \\
\hline Year fixed effect & Yes & Yes & Yes & Yes \\
\hline Firm fixed effect & Yes & Yes & Yes & Yes \\
\hline Adj R-Squared & 0.843 & 0.844 & 0.857 & 0.865 \\
\hline
\end{tabular}

$* * * * *$, and $*$ represent significance at the 1,5 , and 10 percent level, respectively. See Table 2 for a definition of the variables used.

On the other hand, panel A reports controlling shareholders' opportunistic behavior [40] in view of $R \& D$ activities when the wedge is high [18]. Here, the coefficient of $r 1$ shows a negative sign of -2.292 $(\mathrm{t}$-value $=-2.225)$ compared to a positive sign in panel $\mathrm{B}$. The contradictory effects of R\&D affected by the wedge are found in $r 3$, which shows a significant positive coefficient of 0.633 (t-value $=1.695$ ) in panel B while showing a negative coefficient of -1.930 ( $\mathrm{t}$-value $=-2.666)$ in panel A.

The $r 2$ coefficient shows a negative but insignificant value of $-0.558(-0.228)$ in panel A, which indicates that there is no apparent sign of controlling shareholders' opportunistic behavior in capitalized $\mathrm{R} \& \mathrm{D}(r 2)$ in higher wedge conditions. Referring to the six conditions to qualify the economic realizations of development costs (IAS 38), this is because the Korean GAAP accounting treatment for $R \& D$ capitalization requires proof that such $R \& D$ costs will eventually yield future revenues. Thus, opportunistic managers cannot easily dispose of capitalized R\&D for their personal benefit. 


\subsection{Robustness Test: Alternative Wedge Measure}

We perform robustness tests to support our results of Table 4, with an alternative wedge measure, $(1+$ control right $) /(1+$ cash flow right). Panel A of Table 5 reports the results of 671 subsamples, finding that wedge2 is higher than that of panel B for the subsamples, which is lower than its median value of 1.130. Table 5 shows consistent results with those of Table 4 and confirms that a high wedge converts R\&D into an opportunity for controlling owner's private benefit.

Table 5. Additional Test for Alternative Wedge Measure.

\begin{tabular}{|c|c|c|}
\hline VARIABLES & $\begin{array}{c}\text { Panel A } \\
\text { High Wedge2 } \\
q\end{array}$ & $\begin{array}{c}\text { Panel B } \\
\text { Low Wedge2 } \\
q\end{array}$ \\
\hline$r 1$ & $\begin{array}{l}-2.418^{* *} \\
(-2.329)\end{array}$ & $\begin{array}{c}0.229 \\
(0.886)\end{array}$ \\
\hline$r 2$ & $\begin{array}{c}-0.558 \\
(-0.230)\end{array}$ & $\begin{array}{c}12.874 * * * \\
(2.778)\end{array}$ \\
\hline size & $\begin{array}{c}0.432 \text { *** } \\
(6.826)\end{array}$ & $\begin{array}{c}0.377^{* * * *} \\
(8.457)\end{array}$ \\
\hline lev & $\begin{array}{c}0.834^{* * * *} \\
(3.303)\end{array}$ & $\begin{array}{c}1.192^{* * *} \\
(5.425)\end{array}$ \\
\hline roa & $\begin{array}{c}-0.102 \\
(-0.302)\end{array}$ & $\begin{array}{c}0.250 \\
(0.889)\end{array}$ \\
\hline$c f_{0}$ & $\begin{array}{c}0.686^{* * *} \\
(3.863)\end{array}$ & $\begin{array}{c}0.358 \\
(1.587)\end{array}$ \\
\hline salesgrow & $\begin{array}{c}-0.023 \\
(-0.313)\end{array}$ & $\begin{array}{c}0.027 \\
(0.478)\end{array}$ \\
\hline advertise & $\begin{array}{c}-1.573 \\
(-0.375)\end{array}$ & $\begin{array}{c}1.862 \\
(1.182)\end{array}$ \\
\hline capex & $\begin{array}{l}-0.444^{* *} \\
(-2.410)\end{array}$ & $\begin{array}{c}-0.088 \\
(-0.394)\end{array}$ \\
\hline Constant & $\begin{array}{c}-7.670^{* * *} \\
(-6.173)\end{array}$ & $\begin{array}{c}-7.167^{* * * *} \\
(-7.650)\end{array}$ \\
\hline Observations & 671 & 671 \\
\hline Year fixed effect & Yes & Yes \\
\hline Firm fixed effect & Yes & Yes \\
\hline Adj R-Squared & 0.843 & 0.864 \\
\hline
\end{tabular}

*** and ${ }^{* *}$ represent significance at the 1 and 5 percent level, respectively. See Table 2 for a definition of the variables used.

In panel $\mathrm{A}$, the coefficient of $r 1$ is negative and significant as -2.418 ( $\mathrm{t}$-value $=-2.329)$ and the coefficient of $r 2$ is insignificant, 0.558 ( $\mathrm{t}$-value $=-0.230)$, which indicates that controlling shareholders misuse expensed R\&D. Similar to the results in Table 4, a low wedge ratio does not lead to a negative relationship between $R \& D$ and firm values. The results and the interpretations are qualitatively the same as shown in Table 4, confirming the main results.

\subsection{Additional Test: RED Technology Sensitivities}

Theories and empirical studies on corporate competition have consistently shown that high tech firms' competitive advantages in the market depend on R\&D innovation [57]. Thus, firms in high tech industries tend to place their R\&D activities at the center of corporate activities [58]. Based on preferences for and sensitivities to R\&D and its outcomes, we conjecture that firms in high tech are less likely to be affected by controlling shareholders' opportunistic behavior even when the firm has a high wedge. Following the classical segmentation by Francis and Schipper [59], we denote firms belonging to high tech industries as those in chemicals (two-digit Korean industry classification code 20); medical substances and medicine (21); electronics (26); medical, optical, and watch manufacturing (27); electric 
power (28); communication service and manufacturing (61); and computer programming, system integration and management (62). Firms belonging to industries other than those listed above are defined as low tech firms. Table 6 shows the results of subsample analyses based on technology sensitivity. Panel A reports the differences between high-tech and low-tech firms with high wedge ratios; panel B shows low wedge ratios. Panel A shows no significant signs for $r 1$ and $r 2$, while panel B shows positive significant signs for $r 2$. The results imply that high wedge conditions also affect high tech firms.

Table 6. Additional Test: Subsample Test on Technology Sensitivity.

\begin{tabular}{|c|c|c|c|c|}
\hline & \multicolumn{2}{|c|}{$\begin{array}{c}\text { Panel A } \\
\text { High Wedge } 1\end{array}$} & \multicolumn{2}{|c|}{$\begin{array}{c}\text { Panel B } \\
\text { Low Wedge } 1\end{array}$} \\
\hline \multirow[b]{2}{*}{ VARIABLES } & High Tech & Low Tech & High Tech & Low Tech \\
\hline & $q$ & $q$ & $q$ & $q$ \\
\hline \multirow[t]{2}{*}{$r 1$} & -2.290 & -2.592 & 0.093 & 0.270 \\
\hline & $(-1.612)$ & $(-1.199)$ & $(0.037)$ & $(1.242)$ \\
\hline \multirow[t]{2}{*}{$r 2$} & 2.301 & -2.758 & 14.523 * & $14.647^{* * *}$ \\
\hline & $(0.892)$ & $(-1.316)$ & $(1.929)$ & (2.891) \\
\hline \multirow[t]{2}{*}{ size } & $0.707^{* * *}$ & $0.348^{* * *}$ & $0.437^{* * *}$ & $0.365^{* * *}$ \\
\hline & $(5.151)$ & $(5.161)$ & $(6.266)$ & $(6.781)$ \\
\hline \multirow[t]{2}{*}{ lev } & 0.674 & $0.920^{* * *}$ & $1.138^{* *}$ & $1.113^{* * *}$ \\
\hline & $(1.290)$ & $(3.866)$ & $(2.582)$ & $(4.188)$ \\
\hline \multirow[t]{2}{*}{ roa } & 0.229 & -0.111 & -0.015 & 0.280 \\
\hline & $(0.648)$ & $(-0.251)$ & $(-0.037)$ & $(0.789)$ \\
\hline \multirow[t]{2}{*}{$c f o$} & -0.080 & $0.641^{* * *}$ & 0.303 & 0.357 \\
\hline & $(-0.357)$ & (3.281) & (1.266) & (1.143) \\
\hline \multirow[t]{2}{*}{ salesgrow } & -0.213 * & -0.026 & 0.200 & 0.029 \\
\hline & $(-1.968)$ & $(-0.286)$ & (1.483) & $(0.439)$ \\
\hline \multirow[t]{2}{*}{ advertise } & 0.307 & -4.038 & 6.271 & 1.245 \\
\hline & $(0.058)$ & $(-1.009)$ & $(0.992)$ & (1.064) \\
\hline \multirow[t]{2}{*}{ capex } & -0.344 & -0.121 & 0.231 & -0.489 \\
\hline & $(-1.297)$ & $(-0.769)$ & (1.239) & $(-1.428)$ \\
\hline \multirow[t]{2}{*}{ Constant } & $-12.963^{* * *}$ & $-6.092 * * *$ & $-8.422^{* * *}$ & $-6.870^{* * *}$ \\
\hline & $(-4.512)$ & $(-4.550)$ & $(-5.938)$ & $(-5.975)$ \\
\hline Observations & 207 & 464 & 186 & 485 \\
\hline Year fixed effect & Yes & Yes & Yes & Yes \\
\hline Firm fixed effect & Yes & Yes & Yes & Yes \\
\hline Adj R-Squared & 0.863 & 0.862 & 0.876 & 0.862 \\
\hline
\end{tabular}

$* * *, * *$ and ${ }^{*}$ represent significance at the 1,5 , and 10 percent level, respectively. See Table 2 for a definition of the variables used.

\subsection{Diagnostic test: Multicollinearuty and Emdogeneity}

We have performed serial diagnostic tests in order to address potential multicollinearity and endogeneity in the tests. First, we find that variance inflation factors (VIF) for the variables in the regression model report are less than 10 , which indicates that there was no severe multicollinearity issue.

Another concern of the results is endogeneity in the associations between wedge and firm value via $R \& D$ investment. To address the concerns that the suboptimal investment decisions are driven by firm characteristics, such as higher wedges, we execute propensity score matching (PSM). Equation (2) shows the PSM model to draw the matching samples based on firm characteristics, such as firm size, leverage, and profitability, also with year and industry-fixed effects. Applying caliper matching with 0.03 width to drive paired samples, we obtain 860 firm-years.

$$
\text { wedged }=\alpha_{0}+\beta_{1} \text { size }+\beta_{2} \text { lev }+\beta_{3} \text { roa }+ \text { year fixed effects }+ \text { industry fixed effects }+\varepsilon
$$


where wedged = dummy variable equal 1 is wedge 1 is higher that median value of itself, 0 otherwise; size $=$ natural logarithm of market capitalization; lev $=$ total liabilities/total equity; roa $=$ net income/total asset;

Table 7 reports the results of PSM analyses for the same research model (1) to test the valuation effects of $R \& D$ and the wedge. The results confirm the suboptimal R\&D investment of high wedge firms by the negative coefficient of research phased $r 1,-5.702$ ( $\mathrm{t}$-value $=-2.375$ ), and rationally positive investment yields of development phased $r 2$ as 14.314 (t-value $=-3.230)$. The results and the interpretations are qualitatively the same as shown in Table 4, confirming the main results.

Table 7. Valuation Effect of R\&D and the Wedge in the PSM Model.

\begin{tabular}{|c|c|c|}
\hline VARIABLES & $\begin{array}{c}\text { Panel A } \\
\text { High Wedge1 } \\
q\end{array}$ & $\begin{array}{c}\text { Panel B } \\
\text { Low Wedge1 } \\
q\end{array}$ \\
\hline$r 1$ & $\begin{array}{c}-5.702^{* *} \\
(-2.375)\end{array}$ & $\begin{array}{c}0.125 \\
(0.368)\end{array}$ \\
\hline$r 2$ & $\begin{array}{c}3.025 \\
(0.430)\end{array}$ & $\begin{array}{c}14.314^{* * *} \\
(3.230)\end{array}$ \\
\hline size & $\begin{array}{c}0.495^{* * *} \\
(4.163)\end{array}$ & $\begin{array}{c}0.429^{* * *} \\
(9.432)\end{array}$ \\
\hline lev & $\begin{array}{l}1.021 * * \\
(2.340)\end{array}$ & $\begin{array}{c}1.336^{* * *} \\
(6.483)\end{array}$ \\
\hline roa & $\begin{array}{c}-0.142 \\
(-0.237)\end{array}$ & $\begin{array}{c}0.118 \\
(0.429)\end{array}$ \\
\hline$c f o$ & $\begin{array}{l}0.659 * * \\
(2.092)\end{array}$ & $\begin{array}{c}0.413^{* *} \\
(2.077)\end{array}$ \\
\hline salesgrow & $\begin{array}{c}-0.109 \\
(-1.312)\end{array}$ & $\begin{array}{c}0.011 \\
(0.198)\end{array}$ \\
\hline advertise & $\begin{array}{c}0.361 \\
(0.056)\end{array}$ & $\begin{array}{c}2.698 \\
(1.246)\end{array}$ \\
\hline capex & $\begin{array}{c}-0.458 \\
(-1.348)\end{array}$ & $\begin{array}{c}-0.166 \\
(-0.704)\end{array}$ \\
\hline Constant & $\begin{array}{c}-9.076^{* * * *} \\
(-3.778)\end{array}$ & $\begin{array}{c}-8.272 * * * \\
(-8.787)\end{array}$ \\
\hline Observations & 284 & 576 \\
\hline Year fixed effect & Yes & Yes \\
\hline Firm fixed effect & Yes & Yes \\
\hline Adj R-Squared & 0.811 & 0.880 \\
\hline
\end{tabular}

*** and ${ }^{* *}$ represent significance at the 1 and 5 percent level, respectively. See Table 2 for a definition of the variables used.

\section{Conclusions}

This study raised the research question, "What is the underlying cause of the inconsistent relation between R\&D and firm value?" To answer this question, we approach the problem in the investment decision-making process from the view of corporate governance structures. Prior studies indicate that firm value decreases when the control-ownership wedge is high, because capital expenditures, cash holdings, and investments in tangible assets are employed as a tunneling channel of controlling shareholders. We extend prior studies by investigating the effect of $R \& D$ on firm value when the wedge is high or low. Furthermore, we divide R\&D into two phases, expensed and capitalized, and determine which is more frequently utilized as a tunneling channel by controlling shareholders.

Based on a sample of Korean chaebol firms, when the wedge is high, expensed R\&D is significantly and negatively related to firm value. However, capitalized R\&D does not show a significant relationship with firm value. When the wedge is low, expensed R\&D is insignificantly related to firm value and capitalized R\&D is significantly and positively related to firm value. The results show the following implications: First, when the wedge is high, suboptimal R\&D investment decisions are made. 
In particular, controlling shareholders frequently use expensed R\&D to pursue private benefits because managers may exercise greater discretion over investment targets or investment projects. Second, the positive relation between R\&D investment and firm value diminishes in the early phases of $R \& D$.

This study provides evidence that the positive impact of $R \& D$ on sustainable firm growth is not prevalent when the wedge is high. In addition, when the wedge is high, controlling shareholders pursue their private benefits by utilizing R\&D investments as a tunneling channel. Therefore, when the wedge is high, investors and regulators need to monitor activity closely to ensure that R\&D investments, particularly in the early stage, are not used by controlling shareholders to pursue private benefits.

Author Contributions: M.K. and M.-K.C. configure out the original research topic based on their holding concerns over R\&D and corporate governance of Korean affiliated firms. They also extensively review over prior studies and construct the reasoning of our hypotheses; S.K. established research designs and provide analyzing efforts with their interpretation. All the authors co-wrote and revised the manuscript then confirmed the final submission.

Funding: This research received no external funding.

Acknowledgments: Minjung Kang acknowledges a financial support provided by Incheon National University Research Grant in 2016.

Conflicts of Interest: Authors declare no conflict of interest.

\section{References}

1. Lee, P.M.; O'neill, H.M. Ownership structures and R\&D investments of US and Japanese firms: Agency and stewardship perspectives. Acad. Manag. J. 2003, 46, 212-225.

2. Young, G.J.; Charns, M.P.; Shortell, S.M. Top manager and network effects on the adoption of innovative management practices: A study of TQM in a public hospital system. Strateg. Manag. J. 2001, 22, 935-951. [CrossRef]

3. Balkin, D.B.; Markman, G.D.; Gomez-Mejia, L.R. Is CEO pay high-technology firms related to innovation? Acad. Manag. J. 2000, 43, 1118-1129. [CrossRef]

4. Tahak, F.; Barr, S.H. Innovation attributes and category membership: Explaining intention to adopt technological innovations in strategic decision making contexts. J. High Technol. Manag. Res. 1998, 9, 17-34.

5. Sougiannis, T. The accounting based valuation of corporate R\&D. Acc. Rev. 1994, 69, 44-68.

6. Lev, B.; Sougiannis, T. The capitalization, amortization, and value relevance of R\&D. J. Account. Econ. 1996, 21, 107-138.

7. Lev, B.; Zarowin, P. The boundaries of financial reporting and how to extend them. J. Account. Res. 1999, 37, 353-385. [CrossRef]

8. Callen, J.L.; Morel, M. The valuation relevance of R\&D expenditures: Time series evidence. Int. Rev. Financ. Anal. 2005, 14, 304-325.

9. Han, B.; Manry, D. The value relevance of R\&D and advertising expenditures: Evidence from Korea. Int. J. Account. 2004, 39, 155-173.

10. Kim, J.B.; Yi, C.H. Ownership structure, business group affiliation, listing status and earnings management: Evidence from Korea. Contemp. Account. Res. 2006, 23, 427-464. [CrossRef]

11. Bae, K.H.; Kang, J.K.; Kim, J.M. Tunneling or value added? Evidence from mergers by Korean business groups. J. Financ. 2002, 57, 2695-2740. [CrossRef]

12. Claessens, S.; Djankov, S.; Lang, L.H. The separation of ownership and control in East Asian corporations. J. Financ. Econ. 2000, 58, 81-112. [CrossRef]

13. La Porta, R.; Lopez-de-Silanes, F.; Shleifer, A. Corporate ownership around the world. J. Financ. 1999, 54, 471-518. [CrossRef]

14. Anderson, R.C.; Reeb, D.M. Founding family ownership and firm performance: Evidence from the S\&P 500. J. Financ. 2003, 58, 1301-1328.

15. Faccio, M.; Lang, L.H. The ultimate ownership of Western European corporations. J. Financ. Econ. 2002, 65, 365-395. [CrossRef]

16. La Porta, R.; Lopez-de-Silanes, F.; Zamarripa, G. Related lending. Q. J. Econ. 2003, 118, 231-268. [CrossRef]

17. Kahle, K.; Shastri, K. Executive loans. J. Financ. Quant. Anal. 2004, 39, 791-811. [CrossRef] 
18. Masulis, R.W.; Wang, C.; Xie, F. Agency problem at dual-class companies. J. Financ. 2009, 74, $1697-1727$. [CrossRef]

19. Belkhir, M.; Boubaker, S.; Derouiche, I. Control-ownership wedge, board of directors, and the value of excess cash. Econ. Model. 2014, 39, 110-122. [CrossRef]

20. Jiang, L.; Kim, J.B.; Pang, L. Control-ownership wedge and investment sensitivity to stock price. J. Bank. Financ. 2011, 35, 2856-2867. [CrossRef]

21. Wei, K.J.; Zhang, Y. Ownership structure, cash flow, and capital investment: Evidence from East Asian economies before the financial crisis. J. Corp. Financ. 2008, 14, 118-132. [CrossRef]

22. Gompers, P.A.; Ishii, J.; Metrick, A. Extreme governance: An analysis of dual class firms in the United States. Rev. Financ. Stud. 2010, 23, 1051-1088. [CrossRef]

23. Bublitz, B.; Ettredge, M. The Information in discretionary outlays: Advertising, research and development. Account. Rev. 1989, 64, 108-124.

24. Chan, S.; Martin, J.; Kensinger, J. Corporate research and development expenditures and share value. J. Financ. Econ. 1990, 26, 255-276. [CrossRef]

25. Aboody, D.; Lev, B. The Value relevance of intangibles: The case of software capitalization. J. Account. Res. 1998, 36, 161-191. [CrossRef]

26. Ballester, M.; Garcia-Ayuso, M.; Livnat, M. The economic value of the R\&D intangible asset. Eur. Account. Rev. 2003, 12, 605-633.

27. Kothari, S.; Laguerre, T.; Leone, A. Capitalization versus expensing: Evidence on the uncertainty of future earnings from capital expenditures versus R\&D outlays. Rev. Account. Stud. 2002, 7, 355-382.

28. Bhagat, S.; Welch, I. Corporate research \& development investments international comparisons. J. Account. Econ. 1995, 19, 443-470.

29. Morbey, G.K.; Dugal, S.S. Corporate R\&D spending during a recession. Res. Technol. Manag. 1992, 35, 42-46.

30. Bushee, B.J. The influence of institutional investors on myopic R\&D investment behavior. Account. Rev. 1998, 73, 305-333.

31. Dechow, P.; Sloan, R. Executive incentives and the horizon problem: An empirical investigation. J. Account. Econ. 1991, 14, 51-89. [CrossRef]

32. Joos, P.; Plesko, G.A. Valuing loss firms. Account. Rev. 2005, 80, 847-870. [CrossRef]

33. Franzen, L.; Radhakrishnan, S. The value relevance of R\&D across profit and loss firms. J. Account. Public Policy 2009, 28, 16-32.

34. Li, M.Y.L.; Hwang, N.C.R. Effects of firm size, financial leverage and R\&D expenditures on firm earnings: An analysis using quantile regression approach. Abacus 2011, 47, 182-204.

35. Ciftci, M.; Cready, W.M. Scale effects of R\&D as reflected in earnings and returns. J. Account. Econ. 2011, $52,62-80$.

36. Claessens, S.; Djankov, S.; Fan, J.P.; Lang, L.H. Disentangling the incentive and entrenchment effects of large shareholdings. J. Financ. 2002, 57, 2741-2771. [CrossRef]

37. Lins, K.V. Equity ownership and firm value in emerging markets. J. Financ. Quant. Anal. 2003, 38, 159-184. [CrossRef]

38. Lemmon, M.L.; Lins, K.V. Ownership structure, corporate governance, and firm value: Evidence from the East Asian financial crisis. J. Financ. 2003, 58, 1445-1468. [CrossRef]

39. Joh, S.W. Corporate governance and firm profitability: Evidence from Korea before the economic crisis. J. Financ. Econ. 2003, 68, 287-322. [CrossRef]

40. Morck, R.; Shleifer, A.; Vishny, R.W. Management and ownership and market valuation: An empirical analysis. J. Financ. Econ. 1988, 20, 293-315. [CrossRef]

41. Fan, J.; Wong, T.J. Do external auditors perform a corporate governance role in emerging markets? Evidence from East Asia. J. Account. Res. 2005, 43, 35-72. [CrossRef]

42. Bertrand, M.; Mehta, M.; Mullainathan, S. Ferreting out tunneling: An application to Indian business groups. Q. J. Econ. 2002, 118, 121-148. [CrossRef]

43. Johnson, S.; La Porta, R.; Lopes-de-Silanes, F.; Shleifer, A. Tunneling. Am. Econ. Rev. 2000, 90, $22-27$. [CrossRef]

44. Goh, J.; Choi, W.; Cho, J. Changes in chaebol firms' overinvestment after the Asian financial crisis: A long-term perspective. Asia-Pac. J. Account. Econ. 2016, 23, 75-111. [CrossRef] 
45. Jensen, M.; Meckling, W. Theory of the firm: Managerial behavior, agency costs, and ownership structure. J.Financ. Econ. 1976, 3, 305-360. [CrossRef]

46. Sheleifer, A.; Vishny, R. A survey of corporate governance. J. Financ. 1997, 52, 737-783. [CrossRef]

47. Hyundai Motors Is Investigated by the Korea Fair Trade Commission. Available online: https://www.mk.co. kr/news/home/view/2006/10/425695/ (accessed on 4 May 2019).

48. [SK] Two-Fold Suspicions of Mr. Taewon Choi, Chairman of SK. Available online: http://h21.hani.co.kr/arti/ cover/cover_general/7349.html/ (accessed on 4 May 2019).

49. Almeida, H.; Campello, M.; Weisbach, M.S. Corporate financial and investment policies when future financing is not frictionless. J. Corp. Financ. 2011, 17, 675-693. [CrossRef]

50. Jensen, M. Agency cost of free cash flow, corporate finance, and takeovers. Am. Econ. Rev. 1986, 76, 323-329.

51. Degryse, H.; de Jong, A. Investment Spending in the Netherlands: Asymmetric Information or Managerial Discretion?; Working Paper; Tilburg University: Tilburg, The Netherlands, 2001.

52. Hanson, R.; Song, M. Ownership structure and managerial incentives: The evidence from acquisitions by dual class firms. J. Bus. Fianan. Account. 1996, 25, 831-849. [CrossRef]

53. Ahmed, K.; Falk, H. The value relevance of management's research and development reporting choice: Evidence from Australia. J. Account. Public Policy 2006, 25, 231-264. [CrossRef]

54. Lang, L.; Stulz, R. Tobin's q, corporate diversification and firm performance. J. Political Econ. 1994, $102,1248-1280$.

55. Allayannis, G.; Weston, J. The use of foreign currency derivatives and firm market value. Rev. Financ. Stud. 2001, 14, 243-276. [CrossRef]

56. Modigliani, F.; Miller, M.B. Corporate income taxes and the cost of capital: A correction. Am. Econ. Rev. 1963, 53, 433-443.

57. Duystersc, G.; Hagedoorn, J. Core competencies and company performance in the world-wise computer industry. J. High Technol. Manag. Res. 2000, 11, 75-91. [CrossRef]

58. Blonigen, B.A.; Taylor, C.T. R\&D intensity and acquisitions in high-technology industries: Evidence from the US electronic and electrical equipment industries. J. Ind. Econ. 2000, 48, 47-70.

59. Francis, J.; Schipper, K. Have financial statements lost their relevance? J. Account. Res. 1999, 37, $319-353$. [CrossRef]

(C) 2019 by the authors. Licensee MDPI, Basel, Switzerland. This article is an open access article distributed under the terms and conditions of the Creative Commons Attribution (CC BY) license (http://creativecommons.org/licenses/by/4.0/). 